\title{
PERBANDINGAN ANTARA BENTUK PRESBITERIAN DAN KONGREGASIONAL DALAM PEMERINTAHAN JEMAAT
}

\section{Sunarto}

\section{ABSTRAK}

Ada tiga bentuk pemerintahan jemaat yang banyak dianut oleh gereja-gereja sekarang, yaitu: Episkopal, Presbiterian dan Kongregasional. Masing-masing gereja sering mengklaim bahwa sistem yang digunakan merupakan bentuk pemerintahan yang didukung oleh kebenarankebenaran dari Alkitab. Semua bentuk pemerintahan yang pada dasarnya memiliki keunggulan dan kelemahan masing-masing. Apapun sistem yang dianut hendaknya memerhatikan kelemahan yang ada supaya fungsi gereja tidak terhambat dalam memenuhi panggilan dari Allah. Dua aspek penting yang seharusnya turut terlibat secara seimbang dalam pemerintahan jemaat. Aspek pertama, fakta adanya para pejabat gereja (pendeta, penatua dan diaken) yang mendapat mandat untuk mengajar dan mengembalakan jemaat. Aspek kedua, adanya fakta bahwa dalam Gereja Mula-mula, jemaat turut telibat secara aktif dalam menentukan arah pelayanan gerejawi.

\section{PENDAHULUAN}

Gereja ketika dihadirkan oleh Allah di muka bumi pada mulanya belum menghadapi masalah yang berkaitan dengan masalah pemerintahan jemaat. Kelihatannya secara organisasi Gereja Mula-mula belum memiliki sistem pemerintahan jemaat yang ketat. Walaupun belum ada sistem pemerintahan yang baku, tetapi pada hakikatnya Gereja Mula-mula sejak semula sudah ada sistem kepemimpinan jemaat.

Keberadaan rasul-rasul di jemaat dipandang sebagai pemimpin karena fungsinya sebagai pengkhotbah dan pengajar, tetapi corak pemerintahan di gereja pada umumnya sudah menampakkan sistem demokratis. Munculnya keluhan tentang pembagian makanan sehari-hari kepada para janda golongan Hellenis yang berbahasa Yunani diabaikan, rasul-rasul mengajukan usul agar dibentuk satu lembaga khusus yaitu 
"diakonia" atau "diaken". Ini merupakan satu lembaga baru yang dibentuk untuk mengawasi pelayanan meja atau bidang sosial. Suasana demokratis sangat mewarnai pemilihan terhadap orang-orang yang ditunjuk untuk duduk dalam jajaran Diakonia. Setelah memberikan kriteria yang harus dipenuhi (Kis 6:5), rasul-rasul memersilahkan seluruh jemaat untuk menunjuk pilihannya, dengan demikian pilihan itu ditentukan oleh jemaat.

Selanjutnya dalam perkembangannya rasul-rasul juga menetapkan lembaga kepenatuan (penatua/presbyteros/prebister) dan penilik (episkopos/uskup). Walaupun peran kemimpinan para rasul begitu menonjol, tetapi organisasi Gereja Mula-mula juga belum tersusun secara hirarkis. Jemaat-jemaat berdiri sendiri (otonomi atau independen) dan belum ada sistem sinodal atau sistem episkopal. Pasca meninggalnya para rasul pada abad-abad berikutnya kepemimpinan gereja secara berangsurangsur bergeser kepada golongan pejabat-pejabat dalam hal ini ke penatua-penatua dan para diaken. Selanjutnya secara perlahan-lahan sistem susunan hirarkis menjadi semakin berkembang. ${ }^{1}$

Memasuki abad ke dua sampai abad ke lima peran kempimpinan gereja banyak terpusat kepada bapa-bapa gereja. Inilah yang menjadi awal terbentuknya sistem pemerintahan yang bersifat "episkopal" yang dianut oleh Gereja Katolik Roma. Memasuki abad-abad pertengahan hingga terpecahnya gereja menjadi dua blok yaitu Gereja yang di Barat yang berpusat di Roma dan Gereja Timur yang berpusat di Konstantinopel. Perpecahan terjadi pasca konsili di Konstantinopel 869 dan puncaknya terjadi pada tahun $1054 .^{2}$ Situasi ini menjadi menguatnya sistem pemerintahan gereja yang bersifat Episkopal.

Era Reformasi pada abad ke 16 yang dipimpin oleh Martir Luther, John Calvin dan kawan-kawan menjadi awal berkembangnya sistem pemerintahan Prebisterian dan Kongregasional. Menarik untuk ditelaah kembali karena ketiga bentuk pemerintahan yaitu Episkopal, Prebisterian dan Kongregasional banyak diterapkan oleh gereja-gereja di zaman

${ }^{1}$ Dietrich Kuhl, Gereja Mula-Mula Jilid I Tahun 30 - 500 (Batu: Departemen Literatur YPII, 1998), 42-43.

${ }^{2}$ Henry H. Halley, Penuntun Ke Dalam Perjanjian Baru (Surabaya: Yakin, tt), $399,408$. 
modern. Makalah ini akan membandingkan antara bentuk Prebisterian dan Kongregasional dengan menyoroti kekuatan dan kelemahan yang ada.

Untuk memahami lebih jauh perbadingan antara bentuk Prebisterian dan Kongregasional dalam pemerintahan jemaat. Seseorang perlu mengetahui apakah yang dimaksud dengan sistem Prebisterian dalam pemerintahan jemaat? Apakah yang dimaksud dengan sistem Kongregasional dalam pemerintahan jemaat? Bagaimanakah kekuatan dan kelemahan antara sistem Prebisterian dan Kongregasional? Pemahaman ini penting supaya gereja bisa menerapkan bentuk mana yang bisa dipertanggungjawabkan dengan mengatasi berbagai kelemahan yang mungkin bisa terjadi.

\section{TINJAUAN UMUM BENTUK PRESBITERIAN}

\section{Latar Belakang Sejarah Gereja}

Latar belakang berdirinya bentuk pemerintahan gereja Prebisterian tidak bisa dipisahkan dengan terbentuknya Gereja Prebisterian itu sendiri. Berdirinya Gereja Prebisterian sangat terkait erat dengan peristiwa besar yang terjadi di abad ke-16, yaitu terjadinya gerakan Reformasi dalam gereja. Reformasi ini akhirnya melahirkan Gereja Katolik Roma dengan Gereja-gereja Protestan. Ada beberapa tokoh utama yang menggerakkan terjadinya Reformasi pada abad ke-16, yaitu Martin Luther, John Calvin dan Ulrich Zwingli.

Reformasi yang dicanangkan oleh Martin Luther, John Calvin dan Ulrich Zwingli tidak terlepas dari perkembangan yang terjadi di kawasan Eropa. Perkembangan itu terkait dengan kondisi kerohanian atau kegerejaan, sosial dan politik yang terjadi di Eropa, terutama pada abadabad pertengahan. Di bidang kerohanian atau kegerejaan pada abad pertengahan situasi gereja di Eropa Barat berada dalam situasi yang sangat memrihatinkan.

Banyak pejabat gereja memerlihatkan perilaku yang jauh dari kesucian dan kesalehan. Mereka banyak yang hidup dalam kemewahan dan perbuatan yang amoral. Pelayanan, pembinaan dan penggembalaan kepada umat sangat diabaikan, karena mereka dianggap secara otomatis 
sudah menjadi anggota gereja sejak kelahirannya. Kondisi ini sangat meresahkan bagi banyak orang, terutama sejumlah rohaniawan yang masih berusaha memelihara ketertiban hidup dan kemurniaan ajaran gereja. Kondisi tersebut tentunya semakin mendorong untuk memerbaharui dan memurnikan kehidupan dan ajaran gereja. ${ }^{1}$ Disamping secara moralitas kehidupan para rohaniawan banyak mengalami kemerosatan, secara doktrinal gereja banyak mengajarkan halhal yang bertentangan dengan ajaran Alkitab. Sebut saja seperti: penjualan surat penghapusan dosa, doktrin api penyucian, kanonisasi orang-orang suci yang sudah mati dan lain-lain.

Secara sosial politik terjadi perkembangan di kawasan Eropa, timbulnya cita-cita persatuan semua orang Kristen di bawah pimpinan Paus sudah mulai pudar. Timbulnya semangat emansipasi politik di hampir seluruh Eropa. Setiap raja ingin mengatur wilayah kekuasaaannya masing-masing, mereka tidak mau lagi mengakui klaim supremasi gereja atau paus atas nama negara. Khusus di Jerman memang masih ada kaisar yang setia kepada paus dan mengklaim kekuasaan atas seluruh Jerman. Kenyataannya di negeri itu terbagi-bagi dalam banyak wilayah atau negara bagian yang dipimpin oleh raja atau pangeran yang mempunyai otonomi atau kedaulatan sendiri, termasuk dalam bidang keagamaan. Raja-raja itu tidak suka kepada kaisar, dan kaisar lebih sering dipandang sebagai antek paus ketimbang sebagai tokoh pemersatu Jerman. Raja-raja di wilayah Jerman akhirnya banyak berperan mendukung dan memajukan gerakan Reformasi yang dicanangkan oleh Luther dan kawan-kawan.

Di bidang kebudayaan sejak abad ke-15 timbulnya "Renaisans" atau "Renaissance", yaitu semangat untuk kembali ke jayaan masa lalu, untuk itu dipandang perlu untuk menggali sumber-sumber dan menemukan kejayaan masa lalu dan sekaligus mengembangkan ke dalam bentuk yang baru. Maka bangkitlah untuk memelajari sumber-sumber teks klasik (yang aseli) dari zaman kejayaan Yunani-Romawi. Hal ini juga ikut memengaruhi para Reformator untuk memelajari dan memahami Alkitab

1 Jan S. Aritonang, Berbagai Aliran di Dalam dan di Sekitar Gereja (Jakarta: BPK Gunung Mulia, 1999), 24-25. 
ke dalam bahasa aseli, yaitu bahasa Ibrani dan Yunani, termasuk menerjemahkan tulisan Bapa-bapa Gereja mula-mula. ${ }^{2}$

Latar belakang kondisi tersebut akhirnya melahirkan gerakan Reformasi yang ingin memerbaharui kondisi gereja. Reformasi yang dipimpin Martin Luther akhirnya melahirkan Gereja-gereja Lutheran. Reformasi yang dipimpin oleh John Cavin akan melahirkan Gereja Reformed atau Presbiterian yang melatarbelakangi berkembangnya pemerintahan gereja yang disebut dengan sistem Presbiterian.

\section{John Calvin dan Bentuk Presbyterian}

Terbentuknya pemerintahan gereja dengan sistem Prebisterian tidak bisa dipisahkan dengan sejarah berdirinya gereja Prebisterian. Berdirinya Gereja Prebisterian juga tidak bisa dipisahkan dari tokoh gerakan Reformasi, yaitu John Calvin. Harus diketahui bahwa gereja-gereja Protestan di dunia yang menganut ajaran John Calvin (aliran denominasi Calvinis) lebih sering disebut Gereja Reformed atau Presbiterian. Di Indonesia sendiri sekalipun tidak ada satu gereja pun yang memakai nama Calvinis, namun di antara 72 gereja anggota PGI (data tahun 1994; sekarang tentu jumlahnya sudah jauh lebih dari itu), sekurang-kurangnya setengahnya mengaku sebagai Calvinis atau paling tidak mengaku dipengaruhi Calvinisme. ${ }^{3}$

John Calvin dalam bukunya "Institutio" telah meletakkan dasardasar teoritis bagi sistem pemerintahan gereja. Calvin mengatakan: "Kuasa Gereja, yang harus dianggap sebagian terletak pada penilikpenilik jemaat masing-masing, sebagian pada sinode-sinode, baik sinode wilayah maupun sinode am."4 Selanjutnya dalam penjabarannya antara lain dituangkan dalam tulisan kecilnya "Ordonnances Ecclesiastiques" (peraturan-peraturan gereja). Menurut Calvin di dalam gereja ada empat jabatan, yaitu: gembala atau pendeta (pastor), pengajar (doctor), penatua (presbyter), dan syamas atau diaken (diacon). Tugas pendeta memberitakan firman dan melayankan sakramen, bersama dengan para penatua

2 Ibid, 25-26

${ }^{3}$ Ibid, 52

${ }^{4}$ Yohanes Calvin, Institutio Pengajaran Agama Kristen (Jakarta: BPK Gunung Mulia, 2000), 248. 
mengawasi kehidupan jemaat, dan kalau perlu menegur warga gereja yang menyimpang dari ajaran dan peraturan gereja. Jabatan pengajar mencakup semua fungsionaris gereja yang terlibat dalam tugas pengajaran yang berhubungan dengan iman Kristen (guru agama di sekolah, guru katekisasi sampai dosen-dosen teologi). Para penatua (di Jenewa) adalah orang-orang yang ditunjuk pemerintah kota untuk bersama pendeta mengawasi kehidupan gereja. Kepada para diaken atau syamas dipercayakan tugas mengurusi orang-orang sakit, miskin, berkemalangan dan sebagainya.

Khusus tentang jabaran penatua dengan jabatan ini, maka unsur warga gereja masuk ke dalam sistem pemerintahan gereja. Khusus di jemaat Jenewa pada waktu itu, para penatua belum merupakan wakil jemaat atau dipilih oleh warga jemaat; baru dikemudian hari gereja-gereja Calvinis menetapkan pembentukan majelis jemaat atas dasar pemilihan oleh warga. Sedangkan jemaat di Jenewa, para penatua ditunjuk oleh dan merupakan wakil pemerintah, sehingga dalam kerja sama antara pendeta dan penatua tercermin kerja sama antara gereja dan negara demi kesejahteraan rohani penduduk kota pada waktu itu yang identik dengan warga jemaat.

Dalam “Ordonnances Ecclesiastiques” juga diatur tata cara para pejabat gereja berkumpul untuk membicarakan berbagai urusan gereja. Para pendeta membentuk kumpulannya sendiri dan bertemu sekali seminggu, misalnya untuk membahas pengujian calon pendeta. Kemudian kumpulan pendeta bersama penatua yang disebut "consistorium" atau majelis jemaat juga berkumpul sekali seminggu.

Melihat pentingnya jabatan penatua, baik di jemaat Jenewa (semasa Calvin hidup) maupun di gereja-gereja Calvinis di kemudian hari, anggapan di lingkungan gereja-gereja Calvinis yang paling besar wewenangnya adalah para penatua. Sebenarnya tidak demikian, terutama bagi Calvin, karena Calvin justru memberi wewenang terbesar pada pendeta, sesuai dengan tugasnya sebagai pengemban perkara utama di dalam kehidupan jemaat. Peraturan yang disusun Calvin justru mengarahkan gereja itu menjadi gereja pendeta, inilah yang membuat pemerintah kota Jenewa kuatir, kalau-kalau gereja akan menjadi semacam negara di dalam negara. Itulah sebabnya pemerintah kota Jenewa berupaya supaya wewenang pendeta dibatasi dan agar pemerintah 
(melalui para penatua yang duduk dalam majelis jemaat) ikut dilibatkan dalam pemilihan dan pengujian calon pendeta. Calvin tidak menerima tuntutan itu dan memertahankan hak gereja untuk menetapkan sendiri para pelayan Tuhan dan sejalan hak gereja untuk menegakkan disiplin di dalam lingkungannya. ${ }^{5}$ Inilah cikal bakal yang diletakkan oleh Calvin dalam mengatur pemerintahan gereja yang disebut sistem Presbyterian.

Catatan penting yang menjadi pola dasar bagi peletakan struktur pemerintahan gereja presbyterial-sinodal yaitu pada waktu dilangsungkan sidang sinode pertama pada tahun 1559 di Paris bagi gereja-gereja Calvinis di Perancis. Tata gereja ini bertolak dari prinsip bahwa gereja di Perancis terdiri dari jemaat-jemaat. Jemaat setempat dipimpin oleh majelis jemaat, merupakan unit terkecil di dalam gereja. Organisasi yang lebih luas didasarkan pada prinsip bahwa semua jemaat dan semua jabatan mempunyai status yang sama, sehingga tidak ada hierarki seperti di Gereja Roma Katolik. Jemaat di satu wilayah dihimpun dalam suatu sidang yang kemudian disebut "classis", sedangkan jemaat-jemaat di satu propinsi membentuk suatu sinode propinsi. Kalau memungkinkan sekali setahun diadakan sinode nasional yang mengatur dan menetapakan halhal yang bersifat umum dan mendasar. ${ }^{6}$

\section{PRINSIP-PRINSIP DASAR PEMERINTAHAN GEREJA SECARA PRESBITERIAN}

Berikut ini akan diuraikan beberapa prinsip dasar dari sistem pemerintahan gereja secara Presbiterian:

\section{Otoritas Pemerintahan Gereja Lokal}

Sistem Presbiterian adalah bentuk pemerintahan gereja di mana kekuasaan tertinggi berada dalam tangan para penatua. ${ }^{7}$ Di sisi yang lain sistem ini juga tidak menekankan satu orang tertentu untuk secara dominan memiliki otoritas secara tunggal. Otoritas pemerintahan gereja dipegang oleh beberapa orang yang menjadi perwakilan untuk

${ }^{5}$ Jan S. Aritonang, Berbagai Aliran di Dalam dan di Sekitar Gereja, 68-70

${ }^{6} \mathrm{Ibid}, 70-71$.

${ }^{7}$ F.D.Wellem, Kamus Sejarah Gereja (Jakarta: BPK Gunung Mulia, 1997), 210. 
menjalankan kekuasaan itu. Pejabat penting di dalam pemerintahan Presbiterian terletak pada para penatua. ${ }^{8}$

Para penatua dipilih oleh anggota jemaat dalam suatu periode tertentu yang diatur dalam suatu peraturan gerejawi. "Jika di dalam sistem Papal dan sistem Episkopal, struktur gereja dimulai dari atas ke bawah, maka dalam sistem Presbiterial Sinodal struktur dimulai dari bawah ke atas". ${ }^{9}$

Apabila sistem Episkopal arah kebijakan gereja ditentukan oleh satu orang, karena kepemimpinan tertinggi terletak di tangan uskup, dalam sistem Presbiterian arah kebijakan gereja ditentukan beberapa beberapa orang. Gereja setempat secara prinsipil mempunyai hak untuk mengurus keuangan dan harta miliknya sendiri. Ia mempunyai hak untuk memiliki, misalnya gedung-gedung pertemuan, pastori dan lain-lain. Semua urusan gereja tersebut dibicarakan dan diputuskan oleh para pejabat gerejawi setempat.

\section{Fungsi-fungsi dari Pejabat Gereja}

Pikiran dasar dari sistem Presbiterian ialah pimpinan atau pemerintahan Gereja oleh Kristus sebagai Kepala dan Tuhannya. Gereja yang dimaksud bukan hanya gereja sebagai persekutuan, tetapi juga gereja sebagai intitusi atau lembaga. Pimpinan dan pemerintahan itu Ia jalankan dengan perantaran pejabat-pejabat gerejawi sebagai alat atau hambahamba-Nya.

Para pejabat gereja dalam sistem Presbiterian lazimnya disebut sebagai Majelis Jemaat, terdiri dari: pendeta, penatua dan diaken. Para pejabat gerejawi itu mempunyai kedudukan yang sama, tidak ada yang lebih tinggi atau lebih rendah daripada yang lain. Tiap-tiap anggota Majelis Jemaat mempunyai tugasnya sendiri, yang dirumuskan dalam peraturan (Ordonansi) jemaat. Secara umum pada dasarnya semua

${ }^{8}$ Millard J. Erickson, Teologi Kristen, Vulume Tiga (Malang: Gandum Mas, 2004), 348-349.

${ }^{9}$ Lambertus Kattu, Seri Manajemen Gerejami 2, Organisasi Gereja dan Yayasan PI (Malang: Percetakan Lumen Christi, 1997), 96. 
anggota majelis (pendeta dan penatua) bertanggung jawab atas pelayanan jemaat. Pendeta dan penatua memimpin jemaat dan menjalankan disiplin gerejawi. Tugas diaken biasanya membantu orang-orang sakit dan orangorang miskin.

\section{Hubungannya dengan Gereja Lain Satu Denominasi}

Apabila ditingkat gereja lokal ada Majelis Jemaat, untuk tingkatan yang diatasnya ada sidang (pengurus) Klasis dan pusatnya ada Majelis Sinode. Pengurus Klasis terdiri dari wakil Majelis Jemaat dalam satu wilayah, sedangkan Majelis Sinode terdiri dari semua wakil dari Majelis Jemaat secara keseluruhan satu denominasi.

Sidang Klasis maupun Sidang Sinode tidak boleh dianggap sebagai suatu badan pimpinan pemerintahan yang mandiri atau lebih tinggi daripada Majelis Jemaat. Tentang hal ini pada umumnya "Gereja Reformed" tidak berbeda pendapat. Perbedaaan diantara mereka biasanya terletak pada wewenang yang diberikan kepada sidang-sidang gerejawi.

Dalam hal tertentu wewenang Majelis Jemaat setempat mencakup bidang yang lebih luas dari wewenang sidang-sidang gerejawi (Klasis dan Sinode), sebab sidang-sidang gerejawi tidak mempunyai hak kalau tidak diminta untuk mencampuri pelayanan atau persoalan jemaat setempat. Di sisi yang lain, sidang-sidang gerejawi mempunyai wewenang untuk membicarakan dan mengambil keputusan hal-hal yang umum yang menyangkut seluruh gereja. Misalnya masalah pengakuan iman, baptisan, perjamuan kudus dan lain-lain. Keputusan yang menyangkut seluruh gereja bersifat mengikat untuk seluruh gereja untuk ditaatinya. 10

\section{Dasar Alkitab Bentuk Presbiterian}

Alkitab dengan jelas mengajarkan bahwa Kristus adalah kepala atas segala sesuatu. Ia adalah Tuhan dari alam semesta, bukan sekedar sebagai Pribadi ke dua dalam Tritunggal, tetapi juga dalam keadaan-Nya sebagai Pengantara (Mat. 28:18; Ef. 1:20-22; Fil. 2:10-11; Why. 17:14; 19:16. Kristus dalam pengertian yang khusus, Ia adalah kepala gereja di mana gereja adalah tubuh-Nya. Ia berdiri dalam hubunganya yang sangat

${ }^{10}$ J.L. Ch. Abineno, Garis-Garis Besar Hukum Gereja (Jakarta: BPK Gunung Mulia, 2006), 81. 
penting dan hidup dengan gereja, mengisi gereja dengan hidup-Nya dan mengatur gereja secara spiritual (Yoh. 15:1-8; Ef. 1:10, 22-23; 4:15; 5:30; Kol 1:18; 2:19; 3:11.

Alkitab dengan jelas mengajarkan bahwa Kristus adalah kepala gereja, bukan saja dalam hubungannya yang vital dengan gereja, tetapi juga sebagai Legislator dan Raja. Ia juga kepala bagi gereja yang nampak bukan hanya dalam pengertian organik saja, tetapi juga dalam pengertian bahwa Ia adalah pemegang otoritas dan memerintah atasnya (Mat. 16:1819; 23:8, 10; Yoh. 13:13; 1 Kor. 12:5; Ef. 1:20-23; 4:4-5, 11-12; 5:23-24).

Kedudukan Kristus sebagai kepala atas gereja yang nampak ini merupakan bagian prinsip dari kekuasaan yang dimiliki-Nya sebagai hasil dari penderitaaan-Nya. Otoritas-Nya dinyatakan dalam beberapa hal sebagai berikut: a) Ia menetapkan gereja Perjanjian Baru, Mat. 16:18, jadi gereja bukanlah sekedar suatu masyarakat sukarela seperti dipikirkan banyak orang dewasa ini. Jika gereja adalah suatu masyarakat sukarela maka gereja hanya berdasarkan atas kesetiaan para anggotanya saja. b) Kristus menetapkan alat-alat anugerah yang harus dilaksanakan oleh gereja yaitu firman dan sakramen (Mat. 28:19-20; Mrk. 16:15-16; Luk 22:17-20; 1 Kor. 11:23-29). Dalam hal ini tidak ada seorangpun yang memiliki hak melakukan legislasi. c) Kristus memberi gereja ketetapanketetapan serta para pejabat di dalamnya, lalu memberikan kepada para pejabat itu otoritas Ilahi sehingga mereka dapat berbicara dan bertindak dalam nama-Nya (Mat. 10:1; 16:19; Yoh. 20:21-23; Ef. 4:11-12). d) Ia hadir dalam gereja ketika gereja sedang beribadah, dan Ia berbicara dan bertindak melalui para pejabat gereja. Kristus yang adalah Raja gereja memungkinkan para pejabat gereja itu berbicara dan bertindak dengan otoritas (Mat. 10:40; 2 Kor. 13:3). ${ }^{11}$

Alkitab melaporkan dengan jelas setelah para rasul memberitakan Injil, maka terbentuklah jemaat-jemaat dan selanjutnya mereka menetapkan para penatua, penilik jemaat, dan diaken untuk mengurusi kehidupan jemaat. Istilah penatua berasal dari kata Yunani "Presbuteros" yang menekankan wibawa dan kematangan dari jabatan itu. Penatua memiliki otoritas untuk membagikan uang (Kis. 11:30); Mereka

${ }^{11}$ Louis Berkhof, Teologi Sistematika 5, Doktrin Gereja (Surabaya: Lembaga Reformed Injili Indonesia, 1997), 59-60. 
berotoritas untuk membuat keputusan tentang apa yang dimasukkan dalam doktrin ortodoksi (Kis. 15:2, 4, 6, 22; 16:2); mereka menerima laporan tentang pekerjaan misionari (Kis. 20:17; 21:18); mereka harus dihormati (1 Tim 5:17); namun mereka juga tidak boleh menjadi seorang yang diktator (1 Ptr. 5:1-3) dan mereka harus mengunjungi orang sakit dan berdoa bagi mereka, memberikan nasihat dan dorongan (Yak. $5: 14) \cdot{ }^{12}$

Sedangkan istilah Penilik Jemaat berasal dari kata Yunani episkopos. Rupanya pada zaman rasuli tidak dibedakan antara penatua dan penilik, karena Paulus memakai dua istilah tsb. secara identik. Misal Kisah Para Rasul 20:17 memakai istilah "prebyteros"; sedangkan Kisah Para Rasul 20:28; memakai episkopos untuk orang yang sama (termasuk di Tit. 1:5-7). Pada umumnya terdapat beberapa penatua/penilik dalam setiap jemaat (bnd. Fil.1:1, mengingat Filipi adalah kota dan jemaat yang kecil).

Pejabat lain yang diajarkan oleh Alkitab adalah "diakonia". Istilah "diakonia" atau "diaken", merupakan satu lembaga baru yang dibentuk untuk mengawasi pelayanan meja atau bidang sosial. Peran serta jemaat sangat mewarnai pemilihan terhadap orang-orang yang ditunjuk untuk duduk dalam jajaran Diakonia. Setelah memberikan kriteria yang harus dipenuhi (Kisah 6:5), rasul-rasul memersilahkan seluruh jemaat untuk menunjuk pilihannya siapa patut menduduki jabatan sebagai diaken.

\section{TINJAUAN UMUM BENTUK KONGREGASIONAL}

\section{Latar Belakang Sejarah Gereja Kongregasional}

Sama seperti bentuk "Presbiterian" latar belakang sejarah sistem pemerintahan gereja secara "Kongregasional" juga tidak bisa dilepaskan dari peristiwa besar terjadinya reformasi gereja pada abad ke-16. Nama "Kongregasional" mula-mula muncul dalam suatu perkumpulan di Skotlandia (Desember 1557), anggota-anggota dari perkumpulan ini menyebut diri mereka "Congregation of The Lord". Maksud mereka dengan aktivitas-aktivitasnya bukan untuk membasmi Gereja-Negara di Inggris pada waktu itu.

12 Paul Enns, The Moody Handbook Of Theology, Jilid 1 (Malang: Literatur SAAT, 2003), 441. 
Pendiri dari Kongregasional ialah Robert Browne (1550-1633), sesudah menyelesaikan studinya pada "Corpus Christi College" di Cambridge", ia beberapa waktu lamanya bekerja sebagai pengajar di sekitar kota London. Kemudian, ia kembali ke Cambridge dan berkhotbah di berbagai tempat di kota itu. Ia tidak bersedia untuk diangkat dan ditahbiskan menjadi rohaniawan dari Gereja Anglikan. Ia memilih menjadi pemimpin dari suatu kelompok orang, yang memisahkan dari Gereja Anglikan dan membentuk suatu "kongregasi" sendiri.

Robert Browne selanjutnya digantikan oleh Henry Barrow, seorang pengacara yang bertobat. Sama seperti John Green Wood ia beberapa waktu lamanya bekerja sebagai pemimpin kongregasi di Inggris, tetapi keduanya ditangkap dan dijatuhi hukuman mati. Kondisi yang demikian membuat para pengikutnya (para anggota kongregasi) mengambil keputusan untuk berimigrasi. Mula-mula mereka pergi ke Belanda, tetapi kemudian mereka berimigrasi ke Amerika. ${ }^{13}$ Dapat dikatakan bahwa akar utama dari gereja kongregasional (misalnya Gereja Baptis) adalah gerakan Puritanisme di Inggris yang berkembang pada akhir abad ke-16 karena ketidakpuasan dengan kondisi Gereja Negara (Gereja Anglikan). Mereka tidak puas dengan perkembangan reformasi di dalam Gereja Anglikan dan berkerinduan untuk membersihkan gereja dari semua unsur Katolik, oleh karena itu mereka disebut orang Puritan. ${ }^{14}$

Gerakan Kongregasional yang waktunya tidak berbeda jauh dari gerakan reformasi yang digerakan oleh Martin Luther, John Calvin dkk, maka tidak mengherankan jika ajaran para pengikut kongregasional berhubunganan erat dengan ajaran Gereja-gereja Reformed atau Presbiterian. Bertolak dari Inggris, ke Belanda selanjutnya gereja-gereja Kongregasional (abad ke-17) akhirnya berkembang secara luas di Amerika Serikat.

Di bawah Cromwell (1599-1658) para anggota dari Gereja-gereja Kongregasional memeroleh suatu posisi yang kuat. Hal ini mendorong

${ }^{13}$ J.L. Ch. Abineno, Garis-Garis Besar Hukum Gereja (Jakarta: BPK Gunung Mulia, 2006), 84.

${ }^{14}$ Ichwei G. Indra, Identitas Baptis (Surabaya: Pelayanan Mandiri "Mikhael”, 2008,) 3 . 
mereka kepada suatu organisasi yang lebih ketat dan mengikat. Pada tahun 1648 mereka berhasil menyusun "Cambridge Platform, yang terdiri dari 17 pasal, dan pada tahun 1658 menyusun "Savoy Decleration of Faith and Order", sebagai hasil dari konperensi atau sinode di Sovony, yang dihadiri oleh 200 wakil dari 120 Gereja Kongregasional. ${ }^{15}$ Di antara denominasi-denominasi besar yang mempraktikkan sistem pemerintahan kongregasional adalah Gereja Baptis, Gereja Kongregasional, dan kebanyakan kelompok Luteran. ${ }^{16}$

\section{PRINSIP-PRINSIP DASAR KONGREGASIONAL}

Berikut ini akan diuraikan beberapa prinsip dasar dari bentuk pemerintahan gereja secara Kongregasional:

\section{Otonomi Gereja Lokal}

Pemerintahan gereja secara Kongregasional adalah lebih menekankan peran setiap anggota jemaat sehingga menjadikan jemaat lokal pimpinan tertinggi. Setiap jemaat lokal mempunyai otonomi yang mutlak dan tidak dibawah atau di atas dari jemaat lokal yang lain. Maksudnya dengan otonomi ialah bahwa jemaat lokal itu berdiri bebas dan mengatur dirinya sendiri.

Prinsip otonomi berarti bahwa setiap gereja lokal dapat mengatur dirinya sendiri. Setiap jemaat mengangkat gembala sidangnya sendiri serta menentukan sendiri anggaran belanjanya. Gereja lokal membeli dan memiliki sendiri semua iventaris tanpa bertanggung jawab kepada pihak manapun di luar jemaat lokal. Gereja Lokal bisa meminta nasihat kepada gereja yang lain atau pejabat denominasinya di luar jemaat lokal, sekalipun demikian gereja lokal tetap tidak berkewajiban untuk mentaati nasihat tersebut, dan di dalam keputusannya tidak membutuhkan pengesahan atau persetujuan dari pihak mamnapun yang berada di luar gereja lokal. ${ }^{17}$

\section{Demokrasi}

15 J.L. Ch. Abineno, Garis-Garis Besar Hukum Gereja, 84-85.

16 Millard J. Erickson, Teologi Kristen, Volume Tiga (Malang: Gandum Mas, 2004), 354.

17 Ibid, 355 
Prinsip penting yang diterapkan dalam pemerintahan gereja secara Kongregasional adalah menekankan orang perorangan di dalam gereja, seperti demokrasi politik. Sebagian besar keputusan ditentukan melalui pemungutan suara dari semua anggota gereja. ${ }^{18}$ Tentang hal ini Millard J. Erickson mengatakan sebagai berikut: "Tidak ada kekuasaan di luar gereja lokal tersebut yang dapat mendikte perilakunya. Yang dimaksudkan dengan demokrasi ialah bahwa setiap anggota gereja memiliki hak suara. Kekuasaan tertinggi terletak di tangan anggota jemaat lokal. Wewenang tertinggi tidak ada ditangan tokoh atau kelompok tertentu." 19

Konsep demokrasi berarti bahwa wewenang di dalam jemaat lokal berada di tangan setiap anggota jemaat. Pandangan ini sangat menekankan imamat semua orang percaya. Setiap orang percaya dapat langsung menghampiri hadirat Allah tanpa perantara. Sebagaimana yang diingatkan oleh Paulus, setiap anggota atau bagian dari tubuh Kristus memiliki peranan yang menentukan bai kesejahteraan tubuh itu sepenuhnya. ${ }^{20}$

\section{Hubungan dengan Gereja Lain Satu Denominasi}

Setiap jemaat dapat mengadakan penggabungan kerjasama tertentu dengan pihak lain, tetapi bentuk kerjasama tersebut bersifat sukarela. Penggabungan semacam ini dianggap menguntungkan karena beberapa alasan: Pertama, penggabungan ini mewujudkan bentuk kesatuan yang ada di dalam gereja yang tidak kelihatan. Kedua, penggabungan tersebut menyediakan dan meningkatkan persekutuan Kristen dalam jangkauan yang lebih luas daripada yang dimungkinkan dalam satu jemaat lokal. Ketiga, penggabungan tersebut memungkinkan pelayanan dalam tingkat yang lebih efektif daripada yang dapat dilakukan oleh gereja lokal itu sendiri. Pelaksanaan pemberitaaan Injil, pendirian jemaat lokal yang baru, serta kegiatan pemuda pemudi merupakan kegiatan yang lebih efektif apabila dilaksanakan dalam taraf yang lebih luas daripada jemaat lokal.

18 Rick Cornish, 5 Menit Teologi, Kebenaran Maksimun Dalam Waktu Minimum (Bandung: Pioir Jaya, 2007), 297.

19 Millard J. Erickson, Teologi Kristen, Volume Tiga, 354.

20 Ibid, 356-357. 
Mengikuti dan mengikatkan diri dalam kelompok-kelompok semacam itu bersifat sukarela, sebuah jemaat lokal berhak mengakhiri setiap bentuk kerjasama apabila diinginkan. Tidak ada satu kelompok atau pihak manapun yang berhak mengatur penyelenggaraan sebuah gereja lokal. Pemilihan suara dilakukan dengan dasar perwakilan, pada umumnya sesuai dengan besarnya gereja lokal yang terlibat dalam bentuk kerjasama tersebut. ${ }^{21}$ Jadi pemerintahan di daerah atau di pusat hanya berfungsi sebagai penasihat dan hanya bertugas mengkoordinasikan pelayanan penginjilan bersama, pendidikan dan lain-lain yang semacam itu. 22

\section{Fungsi-fungsi Para Pejabat Gereja}

Para pejabat gereja yang dimaksud disini adalah pendeta, penatua (majelis) dan diaken). Di dalam gereja hanya satu otoritas, yaitu Kristus dan Kitab Suci. Kristus memberikan otoritas kepada kongregasi atau kepada anggota-anggota kongregasi secara individu. Pejabat-pejabat tidak memerintah, mereka hanya melayani. Satu-satunya yang memerintah ialah Kristus. Kepada seluruh kongregasi, baik pejabat-pejabat, maupun anggota-anggota kongregasi harus memberikan pertangung jawaban. Tugas penatua-penatua yang menurut ketetapan Allah dipanggil oleh kongregasi ialah: menggembalakan anggota-anggota kongregasi. Tugas itu mereka harus tunaikan sebagai hamba, bukan sebagai tuan. ${ }^{23}$

\section{Dasar Alkitab Bentuk Kongregasional}

Gereja perdana atau yang disebut Gereja mula-mula sebagaimana yang tercatat dalam Kisah Para Rasul, sejak awal seluruh jemaat memilih orang-orang untuk menduduki jabatan tertentu serta ikut serta menentukan kebijaksanaan gereja. Mereka memilih pengganti Yudas Iskariot (Kis 1). Mereka memilih para diaken yang pertama (Kisah 6). Sekalipun tidak ada pernyataan yang jelas pada waktu Paulus dan Barnabas diutus dalam suatu tugas pelayanan (Kis 13:1-3), tetapi sewaktu mereka kembali ke Antiokhia mereka memberikan laporang kepada seluruh jemaat (Kis 14:27).

21 Ibid, 356.

${ }^{22}$ Henry C. Thiessen direvisi oleh Vermon D. Doerksen, Teologi Sistematika (Malang: Gandum Mas, 1995), 494.

${ }^{23}$ L. Ch. Abineno, Garis-Garis Besar Hukum Gereja, 886-87. 
Pada waktu di jemaat ada persoalan masalah pengajaran, seluruh gereja mengutus Paulus dan Barnabas ke Yerusalem untuk untuk membantu persoalan tentang sunat (Kis 15:2-3). Demikian pula yang mengirim jawaban adalah seluruh jemaat Yerusalem. Demikian ditulis dalam Kisah Para Rasul 15:22 sebagai berikut:

Maka rasul-rasul dan penatua-penatua beserta seluruh jemaat itu mengambil keputusan untuk memilih dari antara mereka beberapa orang yang akan diutus ke Antiokhia bersama-sama dengan Paulus dan Barnabas, yaitu Yudas yang disebut Barsabas dan Silas. Keduanya adalah orang terpandang di antara saudara-saudara itu.

Yesus mengecam para murid yang berusaha untuk mendapat kedudukan yang lebih tinggi di atas sesama saudaranya. Ketika muridmurid-Nya berselisih siapa di antara mereka yang terbesar, Yesus berkata kepada mereka:

Raja-raja bangsa-bangsa memerintah rakyat mereka dan orangorang yang menjalankan kuasa atas mereka disebut pelindungpelindung. Tetapi kamu tidaklah demikian, melainkan yang terbesar di antara kamu kamu hendaklah menjadi sebagai yang paling muda dan pemimpin sebagai pelayan. Sebab siapakah yang lebih besar: yang duduk makan, atau yang melayani? Bukankah dia yang duduk makan? Tetapi Aku ada di tengah-tengah kamu sebagai pelayan (Luk. 22:25-27).

Berdasarkan nas tersebut sesungguhnya seorang pemimpin adalah seorang hamba dari semuanya. Sebuah pemahaman yang benar tentang pelayanan akan muncul apabila seorang pemimpin sadar bahwa mereka dipilih oleh orang-orang yang harus merela layani dan bertanggung jawab kepada mereka. ${ }^{24}$

${ }^{24}$ Millard J. Erickson, Teologi Kristen, Volume Tiga, 358-359. 


\section{EVALUASI TERHADAP BENTUK PRESBITERIAN DAN KONGREGASIONAL}

\section{Kekuatan Bentuk Presbiterian}

Hakikatnya bentuk pemerintahan gereja secara Presbiterian menekankan kepemimpinan secara kolektif. Pemerintahan gereja bukan dipimpin oleh satu orang saja, tetapi dipimpin oleh beberapa atau sekelompok orang. Sistem pemerintahan gereja yang demikian jelas menghindarkan keotoriteran seseorang selama menjadi pejabat gerejawi (pendeta, penatua dan diaken).

Sistem yang demikian bertolak belakang dengan apa yang diterapkan dalam Gereja Katolik Roma (Episkopal) bahwa kepemimpin gereja dibawah seorang uskup. Membawai seluruh gereja Katolik di dunia dipimpin satu orang yaitu paus. Sejarah telah mencatat bahwa sejak abad ke-5 uskup Roma (Paus) telah berusaha untuk memerlihatkan dan mengklaim supremasi keunggulannya atas seluruh gereja, paling tidak di Eropa. Akibat pemikiran yang demikian membuat Paus pernah berselisih dengan negara dalam memerebutkan masalah otoritas. ${ }^{25}$

Bentuk Presbiterian memiliki dukungan yang kuat seperti yang diajarkan dalam Perjanjian Baru. Ada banyak contoh di Alkitab bahwa kepemimpinan gereja setelah rasul-rasul digantikan oleh para penatua. Kepemimpinan gereja seperti yang ditunjukkan dalam Alkitab bersifat pluralistas (kolektif) penatua.

Gereja sebagai persekutuan orang-orang percaya dan sebagai lembaga yang dipanggil untuk melakukan tugas dan fungsinya. Tugas dan fungsinya harus dijalankan oleh para pejabat gereja, dalam konteks ini adalah Majelis Jemaat (para penatua). Pendeta dalam sistem Presbiterian merupakan bagian dari Majelis Jemaat. Majelis Jemaat yang bertanggung jawab untuk melakukan tugas-tugas penggembalaan kepada anggota jemaat.

${ }^{25}$ Jan Sihar Aritonang, Garis Besar Sejarah Reformasi (Bandung: Jurnal Info Media, 2007), 5. 


\section{Kelemahan bentuk Presbiterian}

Dalam mengevaluasi bentuk pemerintahan gereja secara Presbiterian harus bertolak dari aturan dari sistem ini. Selama bentuk ini dijalankan secara benar dan konsisten, arah pelayanan gereja akan berjalan dengan baik. Gereja tidak akan dimonopoli oleh satu orang saja, karena semua program gereja harus dibicarakan secara kolektif oleh Majelis Jemaat, yang terdiri dari: Pendeta, Penatua, dan Diaken.

Disisi yang lain peran dari anggota jemaat harus tetap diberi ruang yang cukup untuk memberi masukan-masukan kepada Majelis Jemaat. Usulan-usulan dari anggota jemaat sebaiknya ditampung untuk dibicarakan dan diputuskan oleh Majelis Jemaat. Kelemahan bisa terjadi jika semua program hanya ditentukan oleh Majelis Jemaat tanpa terlebih dahulu meminta masukan dari anggota jemaat,

\section{Kekuatan Bentuk Kongregasional}

Hakikatnya bentuk pemerintahan gereja secara Kongregasional sangat menekankan peran anggota jemaat secara orang perorangan. Semua anggota jemaat memiliki suara yang sama, tanpa peduli status sosial, ekonomi dan pendidikan mereka. Sistem pemerintahan gereja yang demikian jelas menghindarkan keotoriteran (kedikatoran) dari seorang pendeta.

Disamping pendeta dan ada beberapa orang tertentu yang dipilih secara bebas oleh jemaat untuk melakukan tugas-tugas khusus. Hakikatnya dalam pemerintahan gereja, mereka adalah wakil dan hamba dari gereja. Mereka tidak dapat melaksanakan kekuasaan mereka secara bebas atau berlawanan dengan kehendak gereja lokal. Kalau mereka berbuat diluar aturan dapat diberhentikan dari jabatannya tersebut. Semua keputusan penting harus mendapat persetujuan dari seluruh anggota jemaat.

\section{Kelemahan Bentuk Kongregasional}

Keberatan terhadap sistem Kongregasional ialah bahwa sistem ini mengabaikan bukti-bukti Alkitab mengenai wibawa rasuli. Dalam persidangan di Yerusalem yang bersidang adalah para rasul dan para 
penatua, bukan seluruh jemaat. Contoh yang lain, misalnya Paulus pernah mengangkat beberapa penatua (Kisah 14:23) serta menyuruh Titus untuk melakukan hal yang sama (Titus 1:5).

Dalam tataran yang praktis apabila semua hal harus dibicarakan dan memerlukan persetujuan anggota jemaat membuat pelayanan menjadi lambat. Sedangkan untuk beberapa kasus harus memerlukan penanganan dan keputusan yang cepat. Pembahasan masalah doktrinal apabila harus dibicarakan dengan melibatkan seluruh jemaat yang memiliki pemahaman teologi yang dangkal atau sama sekali awam akan membawa hasil yang kurang baik.

\section{PENUTUP}

\section{Kesimpulan}

Masalah pemerintahan gereja pada dasarnya Alkitab memberitahukan dua aspek penting yang seharusnya turut terlibat secara seimbang. Aspek pertama, fakta adanya para pejabat gereja (pendeta, penatua dan diaken) yang mendapat mandat untuk mengajar dan mengembalakan jemaat. Aspek kedua, adanya fakta bahwa dalam Gereja Mula-mula, jemaat turut telibat secara aktif dalam menentukan arah pelayanan gerejawi.

Sistem Presbiterian barangkali bentuk pemerintahan gereja yang berusaha menekankan peran para pemimpin gereja secara kolektif dan membatasi peran anggota jemat karena sudah mewakilkan kepada para pejabat gerejawi. Sedangkan sistem Kongregasional bentuk pemerintahan gereja yang berusaha menekankan peran dari semua anggota jemaat secara perorangan, sehingga peran para pejabat gerejawi dibatasi oleh aturan dan ketentuan gerejawi. Bentuk pemerintahan Presbiterian lebih menyerupai sistem demokrasi perwakilan, sedangkan sistem Kongregasional lebih menyerupai sistem demokrasi secara langsung.

Secara biblikal nampaknya kedua bentuk ini sama-sama mendapatkan banyak dukungan dari Alkitab Perjanjian Baru. Penulis berpendapat sistem Presbiterian merupakan sistem pemerintahan gereja yang cocok diterapkan untuk gereja yang memiliki jumlah anggota yang banyak (besar). Sedangkan bentuk Kongregasional lebih cocok diterapkan untuk gereja yang mempunyai anggota jemaat yang relatif sedikit hingga sampai dalam jumlah yang sedang. 


\section{Rekomendasi}

Bentuk pemerintahan Presbiterian dan Kongregasional pada dasarnya bisa diterapkan dengan memertimbangkan jumlah anggota jemaat karena kedua bentuk ini sama-sama mendapatkan dukungan yang kuat dari Alkitab. Perpaduan antara kedua sistem ini bisa juga merupakan terobosan yang tepat untuk menjaga keseimbangan antara peran para pemimpin (pendeta, penatua dan diaken) dan peran anggota jemaat dalam menjalankan tugas-tugas pelayanan gerejawi.

SUNARTO, menyelesaikan program sarjana muda teologi di Sekolah Tinggi Teologi Injili Efrata (STTI Efrata) Sidoarjo, Sarjana Teologi dan Master of Art di Sekolah Tinggi Teologi Injili Abdi Allah (STT IAA) di Pacet, Mojokerto. Gelar Magister Teologi diperoleh dari Sekolah Tinggi Teologi Baptis Indonesia (STBI) Semarang. Sekarang melayani sebagai dosen dan Ketua STT SAPPI Ciranjang Cianjur. 